\section{Cureus}

\title{
Noninfectious Cloudy Peritoneal Effluent in a Peritoneal Dialysis Patient with Mantle Cell Lymphoma
}

Darlene Vigil $^{1}$, Michael D. Reyes ${ }^{2}$, Sherryl Polak ${ }^{3}$, Yijuan Sun ${ }^{4}$, Lisa Blacklock ${ }^{5}$, Antonios H. Tzamaloukas 6

1. Nephrology, Raymond G. Murphy VA Medical Center and University of New Mexico School of Medicine, Albuquerque, USA 2. Pathology, Raymond G. Murphy VA Hospital, Albuquerque, USA 3. Internal Medicine, Raymond G. Murphy VA Medical Center, Albuquerque, USA 4. Internal Medicine, Raymond G. Murphy VA Medical Center, University of New Mexico School of Medicine, Albuquerque, USA 5. Radiology, University of New Mexico School of Medicine, Albuquerque, USA 6. Internal Medicine, University of New Mexico School of Medicine, Albuquerque, USA

$\square$ Corresponding author: Antonios H. Tzamaloukas, antonios.tzamaloukas@va.gov Disclosures can be found in Additional Information at the end of the article

\section{Abstract}

A 77-year-old man on peritoneal dialysis (PD) presented repeatedly with cloudy spent dialysate containing an elevated mononuclear cell count. He had mantle cell lymphoma diagnosed by colonic polyp biopsy two years before the start of PD. The first episode of cloudy dialysate was treated for peritonitis. However, the culture of the peritoneal fluid was negative and the mononuclear cells were proven to be atypical lymphocytes of the mantle cell lymphoma variety. In addition to the peritoneal effluent, atypical lymphocytes were also found consistently in the patient's blood samples and once in his right pleural effusion. The patient exhibited high peritoneal transport status and clinical features of volume overload raising the question of alterations in the peritoneal transport processes in PD patients with malignancies involving the peritoneal membrane. Distinction between infectious and noninfectious cloudy dialysate and the potential of changes in the peritoneal membrane transport mechanisms are issues that should concern the care of PD patients with cloudy dialysate containing malignant cells.

Categories: Internal Medicine, Nephrology, Oncology

Keywords: peritoneal dialysis, malignancy, mantle cell lymphoma, cloudy peritoneal dialysate

\section{Introduction}

Received 08/27/2018

Review began 09/15/2018

Review ended 09/22/2018

Published 10/04/2018

(C) Copyright 2018

Vigil et al. This is an open access article distributed under the terms of the Creative Commons Attribution License CC-BY 3.0., which permits unrestricted use, distribution, and reproduction in any medium, provided the original author and source are credited.
Peritonitis is the usual cause of cloudy spent peritoneal dialysate in patients on peritoneal dialysis (PD) presenting with or without abdominal pain, fever, nausea, vomiting, or diarrhea. However, the source of cloudy dialysate can be other than infectious. In an informative review, Rocklin and Teitelbaum analyzed the pathogenesis and diagnosis of noninfectious causes of cloudy peritoneal dialysate [1]. The authors distinguished two general sources of cloudy dialysate, conditions causing an increased output of cells in the peritoneal cavity and those leading to intraperitoneal accumulation of compounds causing cloudiness of the dialysate (e.g., chylous ascites).

Cells causing cloudy peritoneal dialysate of noninfectious nature can be leucocytes, red blood cells, or atypical cells [1]. Malignant cells or malignancies causing increased mononuclear cell counts in the dialysate as a cause of noninfectious cloudy dialysate have been reported in a small number of patients [2-8]. We report a case of cloudy peritoneal dialysate due to the 
presence of mantle cell lymphoma cells. This case report illustrates issues created by cloudy dialysate containing malignant cells.

\section{Case Presentation}

A 77-year-old man on PD for five months transferred his care to our unit in January 2018. He had a history of type 2 diabetes mellitus for 40 years and had been followed for chronic kidney disease presumed to be secondary to diabetic nephropathy since 2009. In November 2015, histological examination of colonic polyps removed during routine colonoscopy revealed the presence of prominent nodular aggregates of atypical small to medium size lymphocytes positive for b-lymphocyte antigen CD20 (CD20), cyclin D1, and B-cell lymphoma 2 (BCL-2), with weak expression of lymphocyte antigen CD5 (CD5) and approximately $20 \%$ of the lymphoma cells staining for cellular proliferation marker Ki-67 (Ki-67). The histological diagnosis of mantle cell lymphoma was made. He had no symptoms consistent with lymphoma. Complete blood count revealed modest anemia, and normal white cell and platelet counts. The blood smear did not contain abnormal lymphocytes at that time. Serum lactic dehydrogenase $(\mathrm{LDH})$ level was in the normal range at presentation and throughout the course of his disease. Positron emission tomography-computed tomography (PET-CT) showed scattered metabolically active enlarged lymph nodes in both axillae, mediastinum, and around the upper abdomen around the pancreas. Diffuse metabolic activity was also detected in the spleen, which was enlarged. The patient, who lives at a distance from Albuquerque, New Mexico, chose to be followed by an oncologist closer to his home who suggested postponing the start of antineoplastic treatment until the appearance of signs of disease progression.

Clinical manifestations of lymphoma and signs of disease progression on subsequent surveillance PET-CT studies were absent initially. However, renal function, which was worsening slowly up to that point, worsened rapidly in the second half of 2016, and he was placed on hemodialysis in a dialysis unit close to his home. A percutaneous kidney biopsy performed in December 2016 showed diffuse proliferative (class 4) lupus nephritis, which did not respond to a four-month course of prednisolone and mycophenolate. He had no past medical history of lupus.

In August 2017, he changed his dialysis modality to PD. For the first five months of PD, he was followed in the dialysis unit close to his home. The status of peritoneal transport was investigated by a standard peritoneal equilibration test performed approximately two months after the onset of PD. This test showed a four-hour dialysate-to-plasma ratio for creatinine (four-hour D/P creatinine) of 0.81 which is consistent with high-average transport. Adequacy of azotemic substance removal was tested by standard weekly total (peritoneal plus renal) fractional urea clearance (Kt/V urea) which was 1.81 . Kt/V urea values $\geqslant 1.70$ weekly are considered adequate.

On his first visit to our PD unit he had no abdominal symptoms but the spent peritoneal dialysate was cloudy. Dialysate cell count was as follows: red cells $135 / \mathrm{mm}^{3}$, nucleated cells $693 / \mathrm{mm}^{3}$ (neutrophils 5\%, lymphocytes 79\%, macrophages $15 \%$, mesothelial cells $1 \%$ ). The lymphocytes had an atypical morphological appearance consistent with the diagnosis of mantle cell lymphoma. At the same time, blood hemoglobin was $13.1 \mathrm{~g} / \mathrm{dL}$, hematocrit $38.0 \%$, platelet count $134 \times 103 / \mathrm{mm}^{3}$, and white cells $11.8 \times 103 / \mathrm{mm}^{3}$ with $26 \%$ neutrophils and $69 \%$ lymphocytes disclosing atypical features. He was started empirically on intraperitoneal vancomycin with the presumptive diagnosis of peritonitis. Spent dialysate culture, however, was negative. On each subsequent PD clinic visit, spent peritoneal dialysate contained atypical lymphocytes. Atypical lymphocytes were also found repeatedly in his blood samples.

Recent PET-CT scans showed modest enlargement of several metabolically active lymph nodes 


\section{Cureus}

and spleen. Blood hemoglobin and hematocrit had decreased to $9.9 \mathrm{~g} / \mathrm{dL}$ and $30.4 \%$, respectively, in mid-July 2018. At the same time, white blood cell count was $18.6 \times 103 / \mathrm{mm}^{3}$ with $81 \%$ atypical lymphocytes. Fluid retention, manifested by peripheral edema and moderate right pleural effusion, was present in all his visits to the PD clinic, but became symptomatic with respiratory distress in early July 2018 when he was admitted with the presumptive diagnosis of pneumonia. This diagnosis was not confirmed. However, paracentesis of the right pleural effusion revealed cloudy fluid with $12142 / \mathrm{mm}^{3}$ red cells and $3505 / \mathrm{mm}^{3}$ nucleated cells, $9 \%$ of which were neutrophils and $74 \%$ lymphocytes with atypical appearance. In the same sample, protein concentration was $2.6 \mathrm{~g} / \mathrm{dL}$, LDH $723 \mathrm{U} / \mathrm{L}$, and glucose concentration 107 $\mathrm{mg} / \mathrm{dL}$ while serum glucose was $151 \mathrm{mg} / \mathrm{dL}$.

The following serum laboratory values were obtained recently: albumin $2.4 \mathrm{~g} / \mathrm{dL}, \mathrm{LDH} 432 \mathrm{U} / \mathrm{L}$ (normal range 300-670 U/L), and antinuclear antibodies negative. Serum light chain analysis showed kappa chains $330.5 \mathrm{mg} / \mathrm{L}$ (normal range 3.3-19.4 mg/L), lambda chains $175.3 \mathrm{mg} / \mathrm{L}$ (normal range 5.7-26.3 mg/L), and kappa/lambda ratio 1.89 (normal range 0.26-1.65). Weekly total Kt/V urea was 1.63. The decline over the previous value of Kt/V urea of 1.81 was due to loss of residual renal function. A repeated peritoneal equilibration test showed a high transport state with a four-hour D/P creatinine of 0.86 and ultrafiltration volume of $265 \mathrm{~mL}$. The value of the Kt/V urea was not in the adequacy of dialysis range and the high transport status diagnosed by the last peritoneal equilibration test is known to be associated with fluid retention. The prescription of PD was changed with addition of one daily exchange containing icodextrin to the previous five nocturnal exchanges containing dextrose. In the last PD clinic visit of the patient in August 2018, his edema was substantially reduced and he had not had symptoms related to lymphoma. He is currently discussing the potential advantages and disadvantages of chemotherapy with his oncologist.

Figure 1 shows atypical lymphocytes and a few neutrophils in his peritoneal effluent.

Figure 2 shows a recent PET-CT image with enlarged and metabolically active lymph nodes and an enlarged and metabolically active spleen.

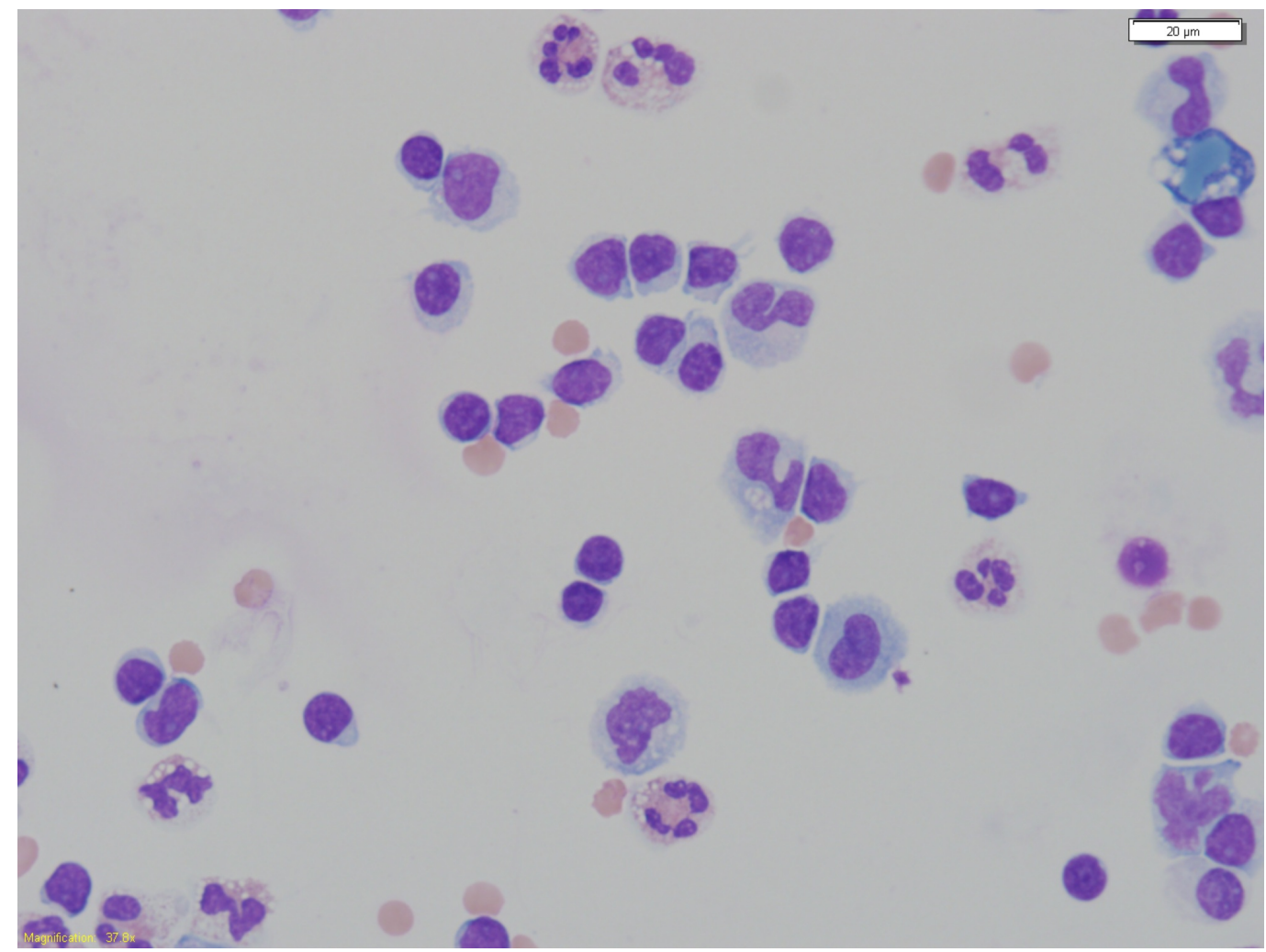




\section{Cureus}

\section{FIGURE 1: Peritoneal fluid.}

The figure shows atypical small to intermediate size lymphocytes with mature chromatin, subtle nuclear irregularities, scant to moderate basophilic cytoplasm and variably prominent nucleoli.

These morphologic findings are compatible with mantle cell lymphoma.

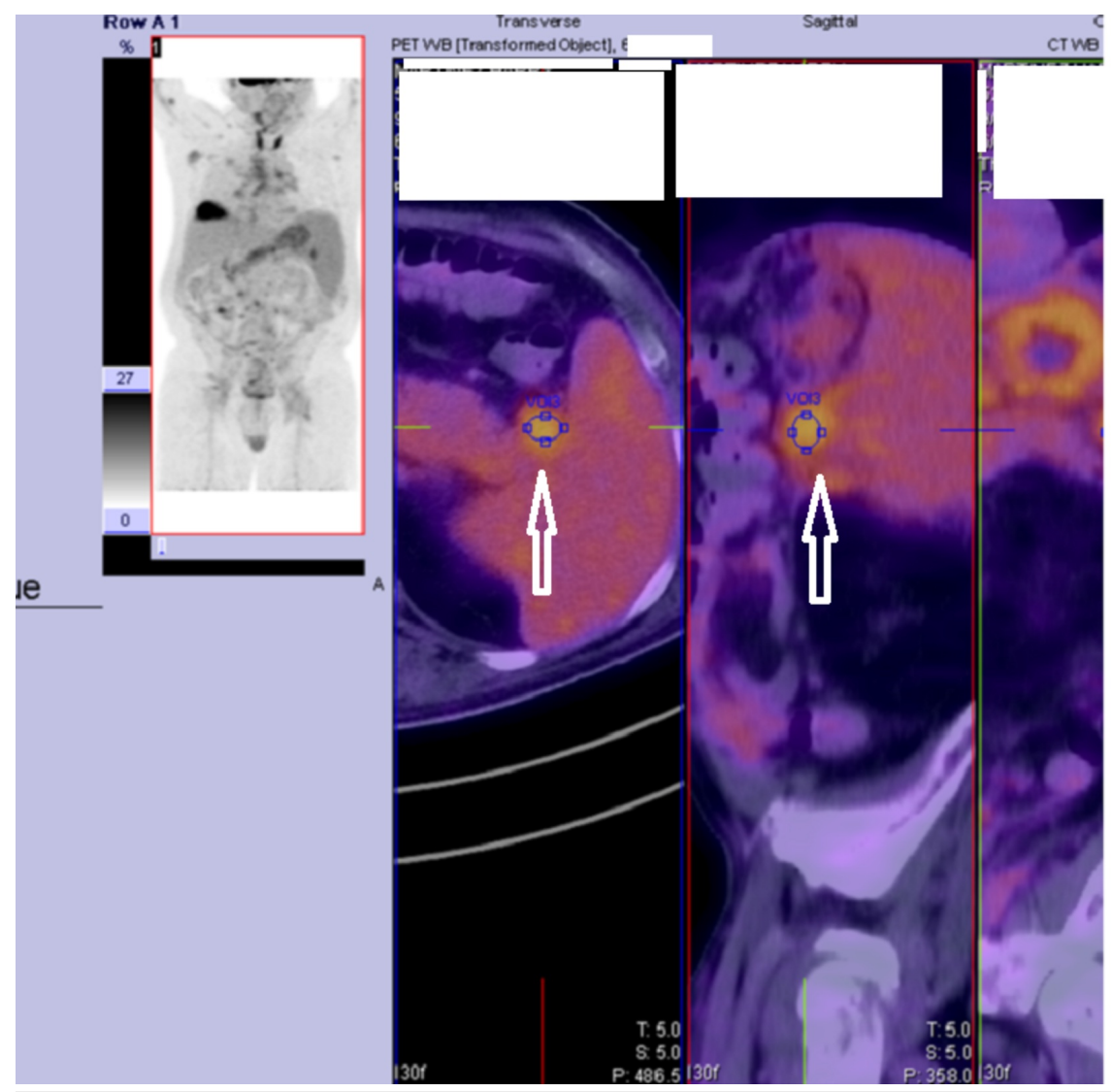

FIGURE 2: Abdominal PET-CT.

PET-CT, positron emission tomography-computer tomography. Arrows: enlarged lymph nodes with increased metabolic activity adjacent to an enlarged spleen, which also exhibits increased metabolic activity.

\section{Discussion}

The management of PD in patients with malignant cells or mononuclear cells associated with malignancy in the peritoneal dialysate faces two questions: (a) is peritonitis present? and (b) has the malignancy altered the peritoneal solute and water transport mechanisms? In conjunction with the other reported cases [2-8], our case report sheds some light on these questions. Table 1 summarizes the key findings of these cases. Including our patient, age of the patients ranged between 47 and 77 years, while four patients were women, three were men, and one report did not provide the gender of the patient [7]. 


\section{Cureus}

\begin{tabular}{|c|c|c|c|}
\hline Reference & Histology & Clinical manifestations & Outcome \\
\hline [2] & $\begin{array}{l}\text { B-cell } \\
\text { lymphoma }\end{array}$ & $\begin{array}{l}\text { Relapsing disease } \times 10 \text { years. Constipation, abdominal discomfort, } \\
\text { mild fever, culture-negative cloudy dialysate. Serum creatinine and } \\
\text { ultrafiltration unchanged }\end{array}$ & $\begin{array}{l}\text { Continued PD. Listeria } \\
\text { peritonitis in two } \\
\text { months leading to } \\
\text { death from sepsis }\end{array}$ \\
\hline [3] & $\begin{array}{l}\text { Renal } \\
\text { carcinoma }\end{array}$ & $\begin{array}{l}15 \text { episodes of culture-negative cloudy dialysate containing } \\
\text { neutrophils and treated with antibiotics. Nephrectomy }\end{array}$ & $\begin{array}{l}\text { Continued PD. Two } \\
\text { peritonitis episodes, } \\
\text { but no episode of } \\
\text { sterile cloudy dialysate } \\
\text { post-nephrectomy }\end{array}$ \\
\hline [4] & $\begin{array}{l}\text { Endometrial } \\
\text { carcinoma }\end{array}$ & $\begin{array}{l}\text { Hysterectomy two years in the past. Abdominal discomfort, leg } \\
\text { swelling, pain }\end{array}$ & $\begin{array}{l}\text { Continued PD. Sudden } \\
\text { death in two weeks }\end{array}$ \\
\hline [5] & $\begin{array}{l}\text { B-cell } \\
\text { lymphoma } \\
\text { large cells }\end{array}$ & $\begin{array}{l}\text { Culture-negative, painless, cloudy dialysate. Malaise, anorexia. } \\
\text { Malignant cells in dialysate and needle biopsy of lymph node }\end{array}$ & $\begin{array}{l}\text { Palliative treatment. } \\
\text { Death in two weeks }\end{array}$ \\
\hline [6] & $\begin{array}{l}\text { Prostatic } \\
\text { carcinoma }\end{array}$ & $\begin{array}{l}\text { Painless cloudy dialysate with atypical cells growing coagulase } \\
\text { negative Staphylococcus and treated with antibiotics. Three more } \\
\text { similar episodes in five months. Prostatectomy }\end{array}$ & $\begin{array}{l}\text { Continued PD. Death } \\
\text { nine months post } \\
\text { prostatectomy } \\
\text { probably from } \\
\text { coronary syndrome }\end{array}$ \\
\hline [7] & $\begin{array}{l}\text { B-cell } \\
\text { lymphoma } \\
\text { large cells }\end{array}$ & $\begin{array}{l}\text { Diagnosed by nasal mass biopsy. Two weeks later, presentation } \\
\text { with decreased ultrafiltration, abdominal pain, and culture-negative } \\
\text { dialysate containing } 80 \% \text { mononuclear cells, and treated with } \\
\text { antibiotics }\end{array}$ & $\begin{array}{l}\text { Chemotherapy. } \\
\text { Continued PD }\end{array}$ \\
\hline [8] & $\begin{array}{l}\text { Hodgkin's } \\
\text { lymphoma }\end{array}$ & $\begin{array}{l}\text { Several relapses. ESKD secondary to chemotherapy. Asymptomatic } \\
\text { cloudy dialysate leading to diagnosis of new relapse }\end{array}$ & $\begin{array}{l}\text { Switched to } \\
\text { hemodialysis. Bone } \\
\text { marrow transplantation }\end{array}$ \\
\hline This case & $\begin{array}{l}\text { Mantle cell } \\
\text { lymphoma }\end{array}$ & $\begin{array}{l}\text { Diagnosed by colonic polyp biopsy } 2 \text { years prior to starting PD. } \\
\text { Culture-negative cloudy dialysate containing atypical cells on } \\
\text { various occasions. Received antibiotics once. Malignant cells also in } \\
\text { blood, pleural fluid. High peritoneal transport, low Kt/V urea due to } \\
\text { loss of residual renal function }\end{array}$ & $\begin{array}{l}\text { Continues PD for one } \\
\text { year. Considering } \\
\text { chemotherapy in view } \\
\text { of apparent disease } \\
\text { progression }\end{array}$ \\
\hline
\end{tabular}

TABLE 1: Reports of cloudy dialysate containing malignant cells or mononuclear cells associated with malignancy.

PD, peritoneal dialysis; ESKD, end stage kidney disease.

The question of presence or absence of peritonitis in the presence of cloudy dialysate was addressed in several case reports summarized in Table 1. This question should be raised regardless of whether there have been prior episodes of culture-negative cloudy dialysate containing malignant cells or the patient does not have clinical manifestations suggesting peritonitis. Informed and timely collaboration between clinicians and laboratory has a chance of reducing errors in this case. Specifically, rapid identification of the type of cells in the spent 
dialysate could lead to timely initiation of antibiotics if the number of neutrophils has increased substantially over previous determinations or to the decision to withhold antibiotics if the neutrophil count in the dialysate has remained low. A positive Gram stain of the dialysate can help the decision to start antibiotics while a negative Gram stain has no diagnostic value. Culture of the dialysate is imperative. However, even in the best of circumstances diagnostic errors can occur. The consequences of not treating a peritonitis episode or treating it late are potentially worse than using antibiotics unnecessarily. Consequently, monitoring of the clinical status and the peritoneal fluid of patients who have not received antibiotics is critical. The option of changing to hemodialysis should also be discussed with the patient.

The second question raised by the presence of atypical cells in the dialysate is whether the malignant process has affected peritoneal ultrafiltration and/or uremic solute removal. This question, which is relevant for patients with longer life expectancy, e.g., those with lymphoma, has not received adequate attention as can be seen in Table 1. Although several patients continued PD for some time after the diagnosis of malignant processes leading to the presence of atypical cells in the peritoneal dialysate, repeated formal testing of the peritoneal transport mechanisms was reported only in our patient. The possibility that either the malignant process or its treatment alters the peritoneal transport processes should be kept in mind. Periodic measurement of Kt/V urea is routinely performed in PD patients. Monitoring of the peritoneal ultrafiltration by frequent clinical evaluation for fluid overload is done routinely. However, periodic performance of peritoneal equilibration test, which is routinely not done repeatedly, should be considered in patients with malignant cells in the peritoneal dialysate.

Lymphoma was responsible for five of the eight patients described in Table 1. In addition to cloudy dialysate containing atypical cells, lymphoma also has been the cause of other clinical manifestations in PD patients [9-11]. One PD patient with acquired immunodeficiency syndrome (AIDS) developed purulent discharge from a rapidly enlarging mass at the site of the PD catheter insertion. Biopsy of the mass revealed plasmablastic lymphoma [9]. A second patient on PD developed two masses in the anterior abdominal wall. These masses, the size of which increased rapidly, were initially thought to represent a PD catheter leak in the abdominal wall, but were proven to be tumors containing large cell B-cell lymphoma [10]. Finally, a patient placed on PD after failure of a renal transplant performed many years earlier was admitted with a clinical picture of sepsis, but was found by bone marrow biopsy to have a late-onset T-cell lymphoma representing post-transplant lymphoproliferative disorder (PTLD) and died within a short time [11].

Our patient had mantle cell lymphoma, which is a B-cell lymphoma arising from cells in the mantle zone of lymphoid follicles expressing the CD5 antigen [12]. Jares and co-investigators provided a detailed analysis of the pathogenetic pathways associated with the varying clinical manifestations of mantle cell lymphoma [13]. The primary mechanism leading to the development of this type of lymphoma consists of a $t(11 ; 14)(q 13 ; q 32)$ translocation causing an overexpression of cyclin D1 [13]. The clinical manifestations may vary from indolent, as they were in our patient at the diagnosis of lymphoma, to severe [14-15]. The low percent of lymphoma cells positive for the Ki-67 proliferation index found in our patient is an indicator of better prognosis [16]. Features of mantle cell lymphoma that are relevant to the manifestations of the disease in our patient include a high frequency of gastrointestinal tract involvement [17] and the indolent finding of the disease in colonic tissue followed by disseminated disease several years later [18]. Circulating atypical cells are frequently encountered and in the most aggressive cases can behave as acute leukemia [19].

Treatment is in general less effective in patients with mantle cell lymphomas than those with other types of lymphomas [14-15]. The current therapeutic approaches are combination chemoimmunotherapy with cytarabin and rituximab followed by autologous stem cell transplantation in young patients and combination immunotherapy followed by the kinase inhibitor ibrutinib 
in older patients [20]. Rapid relapses and poor outcome characterized the treatment of mantle cell lymphoma in the past [14]. The addition of ibrutinib has improved the outcome of treatment of mantle cell lymphoma in elderly patients with mantle cell lymphoma who may not tolerate full doses of antineoplastic agents [20]. Concerns about the risks of the treatment of mantle cell lymphoma led to the decision of the oncologist following our patients to postpone discussion of chemotherapy with the patient until the clinical manifestations of the disease, which were indolent early, worsened.

\section{Conclusions}

In PD patients, mantle cell lymphoma can cause cloudy peritoneal effluent with increased malignant cell count leading to difficulties in the distinction between noninfectious and infectious cloudy dialysate. These difficulties are recurrent and require special attention. The question whether malignancies causing the appearance of atypical cells in the peritoneal effluent affect the peritoneal transport mechanisms and consequently the performance of PD has not been addressed adequately and requires further study.

\section{Additional Information}

\section{Disclosures}

Human subjects: Consent was obtained by all participants in this study. Human Research Committee, Raymond G. Murphy VA Medical Center issued approval Oral approval for case reports is provided by the HRC. Publication, anonymously, of this case report has been approved by the Human Research Committee of the Raymond G. Murphy VA Medical Center. Conflicts of interest: In compliance with the ICMJE uniform disclosure form, all authors declare the following: Payment/services info: All authors have declared that no financial support was received from any organization for the submitted work. Financial relationships: All authors have declared that they have no financial relationships at present or within the previous three years with any organizations that might have an interest in the submitted work. Other relationships: All authors have declared that there are no other relationships or activities that could appear to have influenced the submitted work.

\section{Acknowledgements}

The authors thank MS. Sheryl Reese for assistance with formulation of the images

\section{References}

1. Rocklin MA, Teitelbaum I: Noninfectious causes of cloudy peritoneal dialysate. Semin Dial. 2001, 14:37-40.10.1046/j.1525-139x.2001.00012.x

2. Vlahakos D, Rudders R, Simon G, Ganzanello VJ: Lymphoma-mimicking peritonitis in a patient on continuous ambulatory peritoneal dialysis (CAPD). Perit Dial Int. 1990, 10:165-167.

3. Streather CP, Carr P, Barton IK: Carcinoma of the kidney presenting as sterile peritonitis in a patient on continuous ambulatory peritoneal dialysis. Nephron. 1991, 58:121. 10.1159/000186395

4. Bagnis C, Cabella P, Bruno M, et al.: Cloudy dialysate due to adenocarcinoma cells in a CAPD patient. Perit Dial Int. 1993, 13:322-323.

5. Bargman JM, Zent R, Ellis P, Auger M, Wilson S: Diagnosis of lymphoma in a continuous ambulatory peritoneal dialysis patient by peritoneal fluid cytology. Am J Kidney Dis. 1994, 23:747-750. 10.1016/S0272-6386(12)70289-5

6. Talwar M, Self SE, Ullian ME: Prostate cancer metastatic to the peritoneum in a peritoneal dialysis patient. Perit Dial Int. 2012, 32:570-572. 10.3747/pdi.2011.00281

7. Delgado-Córdova M, Peñaloza JC, Fuentes A, Coronel F: Non-Hodgkin lymphoma mimicking peritonitis in a patient on peritoneal dialysis. Nefrologia. 2014, 34:686-687.

10.3265/Nefrologia.pre2014.Apr.12386 
8. Viray P, Setyapranata S, Holt SG: Hodgkin's lymphoma diagnosed from peritoneal effluent . Perit Dial Int. 2016, 36:350-351. 10.3747/pdi.2015.00119

9. Chen YB, Yu H, Cillani A, Brown JR: AIDS-associated plasmablastic lymphoma presenting at the insertion site of a peritoneal dialysis catheter. J Clin Oncol. 2007, 25:3176-3178. 10.1200/JCO.2007.12.0154

10. Solomon AW, Rajakariar R, Sheaff M, Fan SL: Lymphoma masquerading as a peritoneal dialysis catheter leak. Kidney Int. 2007, 72:294. 10.1038/sj.ki.5002359

11. Dalal P, Bichu P, Dhawan V, et al.: Post-transplant lymphoproliferative disorder-a case of late-onset T-cell lymphoma after failed renal transplant. Adv Perit Dial. 2012, 28:94-96.

12. Rodriguez MA, Pugh WC: Mantle cell lymphomas. Cancer Treat Res. 1996, 85:41-50. 10.1007/978-1-4615-4129-5 4

13. Jares P, Colomer D, Campo E: Molecular pathogenesis of mantle cell lymphoma. J Clin Invest. 2012, 122:3416-3423. 10.1172/JCI61272

14. Dreyling N; European Mantle Cell Lymphoma Network: Mantle cell lymphoma: biology, clinical presentation, and therapeutic approaches. Am Soc Clin Oncol Educ Book. 2014, 191198. 10.14694/EdBook_AM.2014.34.191

15. Sander B, Quintanilla-Martinez L, Ott G, et al.: Mantle cell lymphoma-a spectrum from indolent to aggressive disease. Virchows Arch. 2016, 468:245-257. 10.1007/s00428-015-1840-6

16. Broyde A, Boycov O, Strenov Y, Okon E, Shpilberg O, Bairey O: Role and prognostic significance of the Ki-67 index in non-Hodgkin's lymphoma. Am J Hematol. 2009, 84:338-343. 10.1002/ajh.21406

17. Iwamuro M, Okada H, Kawahara Y, Shinagawa K, Morito T, Yoshino T, Yamamoto K: Endoscopic features and prognoses of mantle cell lymphoma with gastrointestinal involvement. World J Gastroenterol. 2010, 16:4661-4669. 10.3748/wjg.v16.i37.4661

18. Neto AG, Oroszi G, Protiva P, Rose M, Shafi N, Torres R: Colonic in situ mantle cell lymphoma. Ann Diagn Pathol. 2012, 16:508-514. 10.1016/j.anndiagpath.2011.05.001

19. Viswanatha DS, Foucar K, Berry BR, Gascoyne RD, Evans HL, Leith CP: Blastic mantle cell leukemia: an unusual presentation of blastic mantle cell lymphoma. Mod Pathol. 2000, 13:825-833. 10.1038/modpathol.3880144

20. Maddocks K: Update on mantle cell lymphoma. Blood. 2018, 10.1182/blood-2018-03-791392 